\title{
ASSESSING TAXPAYER BEHAVIOR IN UTILIZING E-FILLING TAX SYSTEM WITH THE PERSPECTIVE OF TECHNOLOGY ACCEPTANCE MODEL AND THE THEORY OF PLANNED BEHAVIOR
}

\author{
Maharani Husnunnida*, Subroto Bambang, Ghofar Abdul \\ Faculty of Economics and Business, University of Brawijaya, Indonesia \\ *E-mail: husnunnida20@gmail.com
}

\begin{abstract}
This study aims to assess the factors which influence taxpayer behavior in utilizing e-filling tax system. This study combines Technology Acceptance Model (TAM) and the Theory of Planned Behavior (TPB). The data was collected through a survey method. It took 100 respondents of the personal taxpayers of the Pratama Gresik Utara tax office's (KPP) employee in utilizing the e-filing to submit their tax return (SPT). In order to assess the data, the researchers used Partial Least Square (PLS) statistical method. The finding shows that the intention construct has a positive influence over the e-filling utilization behavior. Behavioral control has a positive influence over the behavior through the e-filing utilization intention. Easy of use, purpose, attitude, subjective norm, and behavioral control have a positive influence over the e-filing utilization intention. Credibility has a negative influence over the e-filing utilization intention. This study involved the Application Service Provider (ASP), Directorate General of Taxes (DJP), and KPP Pratama which have to more pay attention the behavior, intention, easy of use, purpose, attitude, subjective norm, and behavioral control of the taxpayer.
\end{abstract}

\section{KEY WORDS}

E-filling, behavior, technology acceptance model, theory of planned behavior, taxpayer.

Coupled with the increase of needs and current development, information technology grows rapidly. An organization needs it to process the data and run its operational activity. One of the institutions which uses the information technology is the Direktorat Jenderal Pajak (Directorate General of Tax, or DJP) by issuing the decree number KEP-05/PJ/2005 on the procedure for filling of SPT electronically revised in the DJP No.47/PJ/2008.

This study discusses the issue of the e-filing utilization behavior, which is an action or a real activity conducted by an individual (Hartono, 2007). E-filing is a reporting method of the annual and periodic SPT PPh-income tax, completed electronically in real time on the internet through the website of DJP online or the ASP of e-filing. For that matter, the e-filling utilization behavior is a real action conducted by the taxpayer in submitting the annual SPT.

Until today, some of the taxpayers have reported the annual SPT by using e-filing and the others do not use. The government has obligated all civil state apparatus, personnel of Indonesian Military and Indonesian Police to report the annual SPT PPh-income tax, completed electronically (anonymous, 2016). This government's call should be followed by the employees of a state-owned enterprise (BUMN)/province-owned enterprise (BUMD) and all workers from various sectors.

One of the purposes of the implementation of e-filing is improving the compliance of taxpayers to report the SPT. The e-filing is also purposed to ease taxpayer to report the SPT. The purpose of e-filing implementation can not be reached if the taxpayers do not utilize it. Santhanamery and Ramayah (2012) stated that the implementation of information system can be considered successful if only the user can adopt and utilize it for a long term period.

Today's problem of e-filing implementation is the number of e-filing user still not competes with the number of the taxpayer who is listed. DJP targets the number of SPT which submit the SPT for the 2015 year assessment is amounting to 14.4 million. However, as a matter of fact, the number of taxpayers who report their annual SPT for the 2015 year assessment is only 7.96 million taxpayers. Until the time expired, March 2016, the taxpayers 
who reported their SPT manually were 3.3 million. The data showed that the implementation of e-filing did not perform optimally yet since there are still taxpayers who did not utilize it (Anonymous, 2016).

A lot of previous studies showed that the behavioral aspect was the factor of technology information system failed (Hartono, 2007:1). Behavior is the real action which is performed (Akzen, 1991; Hartono, 2007:25). Someone will do an action if s/he has an intention from within. Intention is someone desire to behave (Hartono, 2017: 116).

Even though behavior can be predicted through someone's intention, but the reason how s/he performs it cannot be held directly (Ajzen, 1991). For that matter, the focus of this study is to find out the reason for the rise of the taxpayer's intention and to identify the influence of intention over the behavior to utilize e-filing. The object of this study was all personal taxpayers at the KPP Pratama Gresik Utara who utilize the e-filling tax system. Such an object was chosen since, during the last three years, the number of taxpayers at KPP Pratama who report their annual SPT using e-filing is small compared to the listed taxpayer. The KPP Pratama Gresik Utara is categorized new so requiring input for better performance, especially in terms of e-filing use.

The previous research mostly aimed to identify the factors which influence the intention of the e-filing use (Fu, 2006; Azmi and Bee, 2010; Aziz and Idris; 2014; Gupta et al., 2015). It does not discuss an actual behavior of the e-filing use. This research completes the lack of previous research to add another dependent variable, namely through including the e-filing utilization behavior and observing the construct of the previous research in a particular region in Indonesia.

This study combines the theory of TAM and TPB with a lot of studies (Wang, 2002; Chang et al., 2005; Lu et al., 2010). TAM is used to explain the acceptance of the technology in form of e-filing and TPS to analyze the behavior to utilize it. This research aims to test the influence of the e-filing utilization intention over the e-filing utilization behavior and to examine the determinant of the e-filing utilization intention. Such a determinant is consisted of the ease of use, purpose, credibility, behavior, subjective norm, and behavioral control.

\section{THEORETICAL FRAMEWORK}

E-Filing Use Behavior. Behavior is an action or a real activity conducted by an individual (Hartono, 2007:25). Someone's action in utilizing information technology is one of the behavior types. Individual's behavior appears when s/he has an intention in something (Hartono, 2007:14). Intention is an indication of someone's readiness to behave (Lu et al., 2010).

Ajzen (1991) explained that intention indicated how hard someone wanted to try, or how many efforts s/he planned to do in order to perform a behavior. Individual of this study is the taxpayer who utilizes e-filing. The taxpayers utilize e-filing to perform obligations to report the SPT.

Technology Acceptance Model (TAM). TAM was a theory developed by Davis et al. (1989) based on the model of Theory Reasoned Action (TRA). TAM is a model of the system acceptance of information technology that will be used by the user.

TAM adds two main constructs into the model of TRA, namely purpose and the ease of use. The technology user intends to utilize it if s/he will get a benefit and feels that it can increase his/her performance. The main construct of TAM is the ease of use, purpose, attitude, and intention.

The previous research related to the e-filing utilization intention applied a different construct. Wang (2002) used a construct of the ease of use, purpose, credibility, and intention. Chang et al. (2005) applied the construct of the ease of use, purpose, credibility, attitude, and intention. Lu et al. (2010) explained that Ajzen (1985) used an attitude construct, subjective norm, intention, and behavior.

Theory of Planned Behavior (TPB). TPB is the development of the previous research which lies on the variable of attitude, subjective norm, and behavioral control. Lu et al. (2010) explained that Ajzen (1985) modified the TRA and proposed the TPB to explain human 
behavior pattern. TPB shows that the intention is influenced by attitude, subjective norm, and social control. Ajzen (1985) added a social control construct for TPB to assume the individual behavior limited by his/her shortcoming and limitation from the lack of resources used to have a behavior.

The actual behavior is determined by the behavioral intention. Someone's enthusiasm to have behavior is decided by his/her attitude toward the behavior, subjective norm, and social control. Attitude is an individual's belief on the certain behavior. Subjective norm is an individual's perception of a certain behavior influenced by someone else's judgment. Social control is someone's ease or difficulty to have a behavior. TPB model also shows that social control has influence over the behavior through the intention.

Research model. This study is a combination between the model of TAM and TPB and a construct from a previous research (Wang, 2002; Chang et al., 2005; Lu et al., 2010). The constructs of this research are consisted of ease of use, purpose, credibility, attitude, subjective norm, social control, intention, and behavior. Figure 1 illustrates the model of the research.

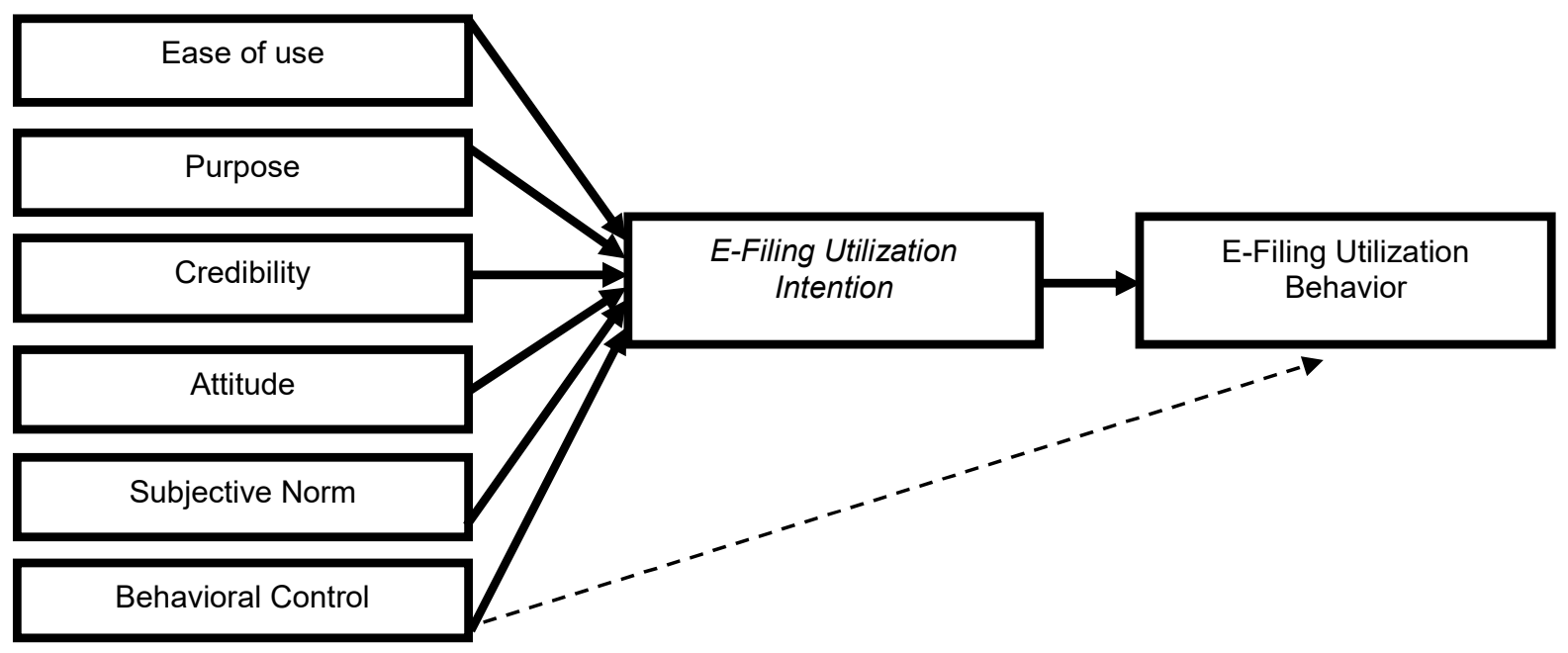

Figure 1 - Research Model

The Hypothetical Development of Ease of Use over the Intention. Wang (2002) explained that the e-filing tax system has to be easy to learn and use to prevent the problem of the lack of system utilization. TAM connects the construct of ease of use and the intention construct through the attitude construct as a mediation variable. Venkatatesh and Davish's (2000) studies changed the relation between the construct of ease of use and the intention construct into the direct relationship.

A lot of researchers (Wang, 2002; Pikkarainen et al., 2004; Noviandhini, 2012; Lie and Sadjiarto, 2012) found that there was a positive relationship between the construct of ease of use and the intention construct. Pikkarainen et al. (2004) observed the construct of ease of use to the utilization intention of online banking system. Noviandini (2012) and Lie Sadjiarto (2013) analyzed the factors influencing the taxpayers' intention to utilize e-filing tax system. The alternative hypothesis which is formulated:

$\mathrm{H} 1$ : Ease of use has a positive influence over the e-filing utilization intention.

The Hypothetical Development of Purpose to the Intention. According to Davis (1989), the utility was someone level of points of view that utilizing a certain system will increase the performance. Wang (2002) explained that the main reason why someone exploits e-filing tax system is that $s /$ he found a useful system to prepare his/her tax return. TAM connects the construct of ease of use with the intention construct. Several studies (Wang, 2002; Wang et al., 2003; Lee et al., 2005; Yi et al., 2006) proven the existence of the purpose construct influence to the intention construct. The alternative hypothesis which is formulated:

$\mathrm{H} 2$ : Purpose has a positive influence over the e-filing utilization intention. 
The Hypothetical Development of Credibility to the Intention. Wang (2002) expressed that in addition to ease of use and the purpose belief, the e-filing utilization intention can be influenced by the user's perception related to the credibility of the security and private matter. If one person feels that $\mathrm{s} / \mathrm{he}$ has a protection from the use of a system, then the user's intention will be more improved. Wang (2002) found that there is a positive influence between the construct of credibility and intention. The alternative hypothesis which is formulated:

H3: Credibility has a positive influence over the e-filing utilization intention.

The Hypothetical Development of Attitude to the Intention. Lu et al. (2010) defined an attitude as the level of someone's negative or positive evaluation of the performance. Another definition was proposed by Ajzen (1991) explaining that the attitude was the level of self-evaluation when someone felt to produce benefits or not produce when assessing behavior. TAM and TPB connect the construct of attitude and the construct of intention. Chang et al. (2005) stated that intention was determined by individual behavior to the attitude. The research result of Chang et al.(2005) and Lu et al. (2010) showed that attitude has a significant influence over the user's intention. The alternative hypothesis which is formulated:

H4: The attitude has positive influence over the e-filing utilization intention

The Hypothetical Development of Subjective Norm to the Intention. Hartono (2007:42) explained that the subjective norm is someone's perception to someone else's belief which would influence his/her intentions to have or not have a behavior which was being considered. According to Lam, Cho, Qu (2007), subjective norm reflected social norm which could influence individual's intention. TPB links the construct of a subjective norm with the construct of intention. A research conducted by Yi et al. (2006) and Lu et al. (2010) found that the construct of subjective norm influenced the construct of intention. With regard to the explanation above, the alternative hypothesis which is formulated:

H5: Subjective norm has a positive influence over the e-filing utilization intention.

Hypothetical Development of Social Control to the intention. Hartono (2007:64) defined behavioral control as an easy or difficulty of perception to act or have a behavior. Ajzen (1991) explained that behavioral control was a construct in TPB applied to various situations at which an individual did not have an enough control of his/herself. A research conducted by Lu et al. (2010) showed that behavioral control has a positive influence on the user's intention. The alternative hypothesis which is formulated:

H6: Behavioral control has a positive influence over the e-filing utilization intention.

Hypothetical Development of Intention to the Behavior. Intention is different with Behavior. Intention is an indication of someone's readiness to have a certain behavior and assumed into a direct antecedent of a behavior (Lu et al., 2010). While behavior is a real action performed by an individual (Hartono, 2007). According to Alleyne and Phillips (2011), when someone has a strong intention, they tended to perform the existing behavior. A research conducted by Lu et al. (2010) proven that the intention construct had a positive influence over the taxpayer behavior to utilize e-filing tax system. With regard tho explanation above, the alternative hypothesis which is formulated:

$\mathrm{H} 7$ : Intention has a positive influence over the e-filing utilization behavior.

Hypothetical Development of Social Control to the Behavior through the Intention. TPB Model shows that the relationship between behavioral control and the behavior is mediated by intention. Ajzen (1991) explained that behavioral control has an influence over the intention and actual action. Behavioral control refers to someone's perception of the ease and difficulty to have a wanted behavior. Social control and intention could predict a behavior because of two reasons, namely intention tended to increase along with the behavioral control and the control social which was felt could be used as the substitute of actual control measurement (Ajzen, 1991). According to the explanation above, the hypothesis which is formulated:

H8: Behavioral control has a positive influence over the behavior through the e-filing utilization intention. 


\section{METHODS OF RESEARCH}

The research population is personal taxpayers listed on the KPP Pratama Gresik Utara, Indonesia. The sample is the personal taxpayer of the employees who utilize e-filing tax system to report the SPT. The researchers choose the sample since according to Astuti (2015), the number of the taxpayer of KPP Pratama Gresik reporting the annual SPT by utilizing e-filing tax system was still low compared to the number of listed taxpayers. KPP Pratama Gresik Utara is categorized new so requiring input for better service, especially in the implementation of e-filing tax system.

The selection of sample was performed through one of the models of nonprobability sampling, namely convenience sampling functions to ease the process of sampling collecting which is fit to the requirement of a sample. This study used a survey method. Questionnaire was the equipment used to collect the data. The research hypothetical review used Partial Least Square statistical method with SamrtPLS 3 program.

\section{RESULTS AND DISCUSSION}

The Description of the Object. The respondent of this study was personal taxpayers who utilize e-filing tax system and are listed on KPP Pratama Gresik Utara. The researchers collected the data from 22 May until 2 June 2017. The number of questionnaire spread was 120 and the ones could process were 100 questionnaires or around to $83.3 \%$. The number of samples and the rate of questionnaire return are shown in Table 1.

Table 1 - Sample and the Rate of Questionnaire Return

\begin{tabular}{|l|c|c|}
\hline \multicolumn{1}{|c|}{ Description } & Total & Percentage \\
\hline Spread Questionnaire & 120 & $100 \%$ \\
\hline Unreturned Questionnaire & $(6)$ & $5 \% \%$ \\
\hline Returned Questionnaire & 114 & $95 \%$ \\
\hline Incompleted Questionnaire & $(9)$ & $7,5 \%$ \\
\hline Unprocessed Questionnaire & $(5)$ & $4.1 \%$ \\
\hline Processed Questionnaire & 100 & $83,3 \%$ \\
\hline
\end{tabular}

Table 2 displays the respondent demography data.

Table 2 - Respondent demography data

\begin{tabular}{|c|c|c|c|}
\hline No & Description & Total & Percentage \\
\hline \multirow[t]{5}{*}{1} & \multicolumn{3}{|l|}{ Employment: } \\
\hline & a. Civil Servant & 41 & $41 \%$ \\
\hline & BUMN employee & 36 & $36 \%$ \\
\hline & Private employee & 18 & $18 \%$ \\
\hline & etc & 5 & $5 \%$ \\
\hline & Total & 100 & $100 \%$ \\
\hline \multirow[t]{4}{*}{2} & Sex: & & \\
\hline & Gender & 43 & $43 \%$ \\
\hline & Female & 57 & $57 \%$ \\
\hline & Total & 100 & $100 \%$ \\
\hline \multirow[t]{6}{*}{3} & Age & & \\
\hline & $20-30$ years old & 31 & $31 \%$ \\
\hline & $31-40$ years old & 45 & $45 \%$ \\
\hline & $41-50$ years old & 19 & $19 \%$ \\
\hline & $51-60$ years old & 4 & $4 \%$ \\
\hline & Total & 100 & $100 \%$ \\
\hline \multirow[t]{7}{*}{4} & The latest job & & \\
\hline & Diploma Program & 38 & $38 \%$ \\
\hline & Undergraduate Program & 54 & $54 \%$ \\
\hline & Postgraduate Program & 3 & $3 \%$ \\
\hline & Doctoral Program & 2 & $2 \%$ \\
\hline & etc & 3 & $3 \%$ \\
\hline & Total & 100 & $100 \%$ \\
\hline
\end{tabular}




\begin{tabular}{|llll|}
\hline \multicolumn{4}{|l|}{ Continue of Table 2 } \\
\hline 5 & E-filing tax system use: & \\
& a. $\quad$ Yes & 100 & $100 \%$ \\
& b. No & 0 & $0 \%$ \\
\hline \multicolumn{7}{|l}{ Total } & 100 & $100 \%$ \\
\hline 6 & An experience to use e-filing: & & \\
& a. $\quad<1$-year experience & 21 & $21 \%$ \\
& b. $\quad 1<x<2$-year experience & 60 & $60 \%$ \\
& C. $\quad>$ 2-year experience & 19 & $19 \%$ \\
\hline
\end{tabular}

Test Validity and Reliability. There are two types of test validity, namely convergent validity, and discriminant validity. The Parameter used in the validity convergent is the value of AV more than 0.5 , communality value is more than 0.5 , and the value of factor loading is more than 0.7 . The value of AVE and the value of communality of all constructs is more than 0.5 . The value of loading factor of all indicators is more than 0.7 . According to the result, it can be concluded that construct and indicator have fulfilled convergent validity. Two parameter used in the discriminant validity is the value of AVE square root which has to be higher than the correlation of variable latent and the value of cross loading has to be more than 0.7 in one variable. The value of cross loading in one variable is more than 0.7 so can be concluded that the construct and indicator used in this research have fulfilled the discriminant validity.

The parameter used to assess reliability from the Cronbach's alpha is more than 0.6 and composite reliability more than 0.7 . All values of Cronbach's alpha are more than 0.6 and the value of composite reliability is more than 0.7 . With regard to the result, it can be concluded that the data and result of measurement are reliable. Those three tests have been conducted and the result shows that this study has fulfilled the requirement of convergent validity, discriminant validity, and reliability. The conclusion is that all constructs and indicator utilized in this study is valid and reliable.

Hypothesis Assessment. A parameter to assess one-tailed hypothesis is the value of $t-$ statistics has to be more than 1.64. The Hypothesis will be accepted if the value of t-statistics is more than 1.64 and hypothesis will be rejected if the value of t-statistics is less than 1.64. Table 3 shows which shows the value of path coefficient.

Table 3 - Path coefficient value

\begin{tabular}{|c|c|c|c|c|c|c|}
\hline Hypothesis & Construct & Original Sample & Sample Mean & Standard Deviation & T-Statistics & Decision \\
\hline H1 & PKP $\rightarrow$ MP & 0,143 & 0,147 & 0,069 & 2,063 & Accepted \\
\hline H2 & PKG $\rightarrow$ MP & 0,192 & 0,190 & 0,090 & 2,138 & Accepted \\
\hline H3 & PKR $\rightarrow$ MP & $-0,072$ & $-0,056$ & 0,091 & 0,791 & Rejected \\
\hline H4 & S $\rightarrow$ MP & 0,256 & 0,250 & 0,064 & 3,982 & Accepted \\
\hline H5 & NS $\rightarrow$ MP & 0,140 & 0,131 & 0,080 & 1,751 & Accepted \\
\hline H6 & KP $\rightarrow$ MP & 0,346 & 0,342 & 0,102 & 3,392 & Accepted \\
\hline H7 & MP $\rightarrow$ P & 0,753 & 0,757 & 0,039 & 19,213 & Accepted \\
\hline & KP $\rightarrow \mathrm{P}$ & 0,677 & 0,682 & 0,048 & 14,111 & \\
H8 & KP $\rightarrow$ M & 0,325 & 0,323 & 0,097 & 3,336 & Accepted \\
& $\mathrm{M} \rightarrow \mathrm{P}$ & 0,602 & 0,612 & 0,113 & 5,344 & \\
& $\mathrm{KP} \rightarrow \mathrm{M} \rightarrow \mathrm{P}$ & 0,175 & 0,167 & 0,120 & 1,460 & \\
\hline
\end{tabular}

Hypothesis 1 states that ease of use has a positive influence over the e-filing utilization intention. The result shows that t-statistics value is 2.063 at which higher than the value of $t-$ table by 1.64 . The value of $\beta$ is 0.412 ; therefore, indicating a positive relationship between the ease of use and e-filing utilization intention. According to the result, then hypothesis 1 is accepted. This is consistent with the research conducted by Wong (2002), Chang et.al. (2005), Fu et al. (2006), Yi et al. (2006), Azmi and Bee (2010), and Lie and Sadjiarto (2013). When the taxpayer considers that e-filing tax system is easy to use; therefore, the desire of the taxpayers to use e-filing in reporting SPT increases.

Hypothesis 2 states that purpose has a positive influence over the e-filing utilization intention. The result shows that the value of t-statistics, 1.64 , is higher than the value of $t$ - 
table by 2.138 . The value of $\beta$ is positive, 0.192 , so indicating the positive relationship between purpose and the e-filing utilization intention. According to the result, hypothesis 2 is accepted. This study supported the previous study conducted by Wang (2002). The result is staying the same with the previous study conducted by Lee et al. (2005), Chang et. al. 2005) et. al. (2006), Yi et. al. (2006), and Azmi and Bee (2010).

Hypothesis 3 states that the credibility has a positive influence over the e-filing utilization intention. The result of this study shows that the value of $\beta$ is -0.072 which indicates negative and the value of t-statistics of the credibility construct to the e-filing utilization intention is 0.791 which is less than 1.64 . It shows that credibility has a negative influence over the e-filing utilization intention. With regard to the result, hypothesis 3 is rejected.

According to the finding, it can be said that the respondents feel that if the e-filing tax system safe or not is not important. A significant influence over the e-filing utilization intention can be caused by the factor of behavioral control. When the taxpayer is sure that they are able to utilize e-filing tax system, then if the e-filing is safe or not will be neglected. The matter also can be seen from the respondent's demography data which mostly have the experience to use the e-filing tax system for one to two years. Through the experience gotten by the taxpayer, so it can be said that they have been accustomed to and are able to use the e-filing easily which causes continuously use. In addition, considering the latest education of the taxpayer dominated by the bachelor's degree so the taxpayers can be said able to operate a computer and use the e-filing tax system.

Hypothesis 4 states that the attitude has a positive influence over the e-filing utilization intention. The finding shows that the value of t-statistics is higher than the value of t-table by 3.982. The value of $\beta$ is 0.256 which positive so indicating a positive influence between the attitude and the e-filing utilization intention. With regard to the result so hypothesis 4 is accepted. This result is consistent with the previous study conducted by Chang et al. (2005) and Lu et al. (2010). The better the attitude of the taxpayer, the higher the increase of the taxpayer's intention to use the e-filing.

Hypothesis 5 states that the subjective norm has a positive influence over the e-filing utilization intention. The result shows that the value of t-statistics is 1.751 , it is higher than the value of t-table by 1.64 . The value of $\beta$ is 0.140 which indicates positive so proving that the subjective norm has a positive influence over the e-filing utilization intention. For that matter, hypothesis 5 is accepted. The more positive information delivered to the taxpayer, the higher the number of the taxpayer who is intentioned in using the e-filing. The result is consistent with the previous study conducted by Venkatesh and Davis (2000), Yi et al. (2006). and Lam, Cho, and Qu (2007), and Lu et. Al (2010)

Hypothesis 6 states that behavioral control has a positive influence over the e-filing utilization intention. The finding shows that the value of $\beta$ is 0.346 which indicates positive and the value of t-statistics of the behavioral control construct to the e-filing utilization intention from the t-table (1.64) is 3.92. It shows that behavioral control has a positive influence over the e-filing utilization intention. For that matter, $\mathrm{H} 6$ is accepted. This study supports the previous study conducted by Lu et al. (2010) if the taxpayer feels that they can control their behavior to use the e-filing and have a needed resource, thus the taxpayers tend to choose to use the e-filing tax system.

Hypothesis 7 states that the e-filing utilization intention has a positive influence over the behavior to use the e-filing. The result shows that the value of t-statistics is 19.213; it is higher than the value of t-table by 1.64 . The value of $\beta$ is positive by 0.753 ; therefore, it shows that the e-filing usage intention has a positive influence over the e-filing usage intention. For that matter, hypothesis 7 is accepted. The higher the intention of the taxpayer to use the e-filing tax system, the more possible the taxpayer will use it. The result supports the previous study conducted by Ajzen (1991) and is consistent with the result of study conducted by Venkatesh and Davis (2000) and Lu et al. (2010)

Hypothesis 8 is an indirect relationship so the researchers conducted a mediation effect test developed by Baron and Kenny (1986). The first model assesses the influence of behavioral control over the behavior. The result shows a significant influence marked by the 
positive value of $\beta$ by 0.677 and the value of t-statistics by 14.111 . The second model assesses the influence of behavioral control to the e-filing utilization intention as the mediation variable. The result indicates the significant influence represented by the positive value of $\beta$ by 0.325 and the value of $t$-statistics is higher than t-table by 3.336 . The third model simultaneously assesses the influence of behavioral control over the intention and behavior. The finding shows that the relationship between social control and the behavior has the value of t-statistics by 1.460 and the relation between intention and behavior has a tstatistics value which is higher than the t-table by 5.344 with the value of $\beta$ positive by 0.602 . It shows that behavioral control has a positive influence over the e-filing utilization behavior through the intention as the utter mediation variable. For that matter, hypothesis 8 is accepted.

\section{CONCLUSION}

With regard to the explanation above, the conclusion is that the taxpayer behavior in utilizing e-filing tax system is decided by the e-filing utilization intention. The higher the desire of the taxpayer to use the e-filing tax system, the higher the possibility of the taxpayers to use the e-filing tax system. The e-filing utilization intention is influenced by the ease of use, attitude, and subjective norm. The study shows that the e-filing utilization intention is also determined by the behavioral control through the intention. Enthusiasm plays a role as a full mediation variable in the relationship between behavioral control and the e-filing utilization behavior.

The implication of this study can explain the model of TAM and TPB as the basic theory which predicts behavior and strengthens the previous result. This finding also becomes additional empirical evidence by strengthening the model of TAM and TPB to identify technology utilization behavior, especially the e-filing tax system. The result of this study is applied to the practice of design, socialization, and implementation of e-filing. This study can be an evaluation that in order to increase the e-filing use, the DJP and KPP have to be able to increase the intention of the taxpayer and provide the required factors.

The limitation of this research is related to the method of sample selection. The researchers used convenience sampling method. With regard to the result, the researchers cannot generalize this finding. The researcher's suggestion for the same topic and subject is considering again the method of sample selection used, so the result can be generalized.

\section{REFERENCES}

1. Ajzen, I. (1991). The Theory of Planned Behavior. Organizational Behavior and Human Decision Process, 50, 179-211.

2. Alleyne, P., \& Phillips, K. (2011). Exploring Academic Dishonesty Among University Students in Barbados: An Estension to the Theory of Planned Behavior. Journal of Academic Ethics (9), 323-338.

3. Author, I. (2016). E-Filing, Cara Mudah, Cepat, dan Aman Lapor Pajak [On-line] Avalibale http://www.pajak.go.id.

4. Astuti, I. N. (2015). Analisis Penerapan E-Filing sebagai Upaya Meningkatkan Kepatuhan Wajib Pajak dalam Penyampaian Surat Pemberitahuan (SPT) Tahunan pada Kantor Pelayanan Pajak Pratama Gresik Utara. Surabaya State University.

5. Azis, S.A., \& Idris, K. M.. (2014). Does Design Matter in Tax E-Filing Acceptance? Social and Behavioral Sciences, 164, 451-457.

6. Azmi, A. C., \& Bee, N. L. (2010). The Acceptance of The E-Filing System by Malaysian Taxpayers: A Simplified Model. Electronic Journal E-Government, 8 (1), 13-22.

7. Chang, I. C., Li, Y. C., Hung, W. F., \& Hwang, H. G. (2005). An Empirical Study on The Impact of Quality Antecedents on Tax Payers' Acceptance of Internet Tax-Filing Systems. Government Information Quarterly, 22, 389-410.

8. Davis, F. D. 1989. Perceived Usefulness, Perceived Ease of Use, and User Acceptance of Information Technology. MIS Quarterly, 13 (5), 319-339. 
9. Davis, F. D., Bagozzi, R. P., \& Warshaw, P. R. (1989). User Acceptance of Computer Techonology: A Comparison of Two Theoretical Models. Management Science, 982.

10. Fu, J. R., Farn, C. K., \& Chao, W. P. (2006). Acceptance of Electronic Tax Filling: A Study of Taxpayer Intentions. Information \& Management, 43, 109-126.

11. Gupta, G., Zaidi, S. K., Udo, G., \& Bagchi, K. (2015). The Influence of Theory of Planned Behavior, Technology Acceptance Model, and Information Systems Success Model on the Acceptance of Electronic tax Filling System in Emerging Economy. The International Journal of Digital Accounting Research, 15, 155-185.

12. Hartono, H. M. J. (2007). Sistem Informasi Keperilakuan. Yogyakarta: CV. Andi Offset.

13. Lam, T., Cho, V., \& Qu, H. (2007). A Study Of Hotel Employee Behavioral Intentios Toward Adoption Of Information Technology. International Journal of Hospitality Management, 26, 9-65.

14. Lee, H. Y., Lee, Y.K., \& Kwon, D. (2005). The Intention To Use Computerized Reservation Systems:The Moderating Effects Of Oganization Support And Supplier Incentive. Journal Of Business Research, 58, 1552-1561.

15. Lie, I., \& Sadjiarto. (2013). Faktor- Faktor yang Mempengaruhi Minat Wajib Pajak untuk Menggunakan E-Filing. Jurnal Tax \& Accounting Review, 3 (2).

16. Lu, C. T., Huang, S. Y., \& Lo, P. Y. (2010). An Empirical Study of On-Line Tax Filling Acceptance Model: Integrating TAM and TPB. African Journal of Business Management, 4 (5), 800-810.

17. Noviandini, N. C. (2012). Pengaruh Persepsi Kebermanfaatan, Kemudahan Penggunaan Penggunaan, Dan Kepuasan Wajib Pajak Terhadap Penggunaan E-Filing Bagi Wajib Pajak Di Yogyakarta. Jurnal Nominal, 1 (1).

18. Pikkarainen, T., Pikkarainen, K., Karjaluoto, H., \& Pahnil, S. (2004). Consumer Acceptance of Online Banking. Internet Research, 14 (3), 224-235.

19. Santhanamery, T., \& Ramayah, T. (2012). Continued Usage Intention of E-Filing System in Malaysia: The Role of Optimism Bias. Social Behavioral Sciences, 65, 397-403.

20. Venkatesh, V., \& Davis, F. D. (2000). A Theoretical Extension Of The Technology Acceptance Model: Four Longitudinal Field Studies. Management Science, 186.

21. Wang, Y. S. (2002). The Adoption of Electronic Tax Filling Systems: An Empirical Study. Government Information Quarterly, 20, 333-352.

22. Yi, M. Y., Jackson, J. D., Park, J. S., \& Probst, J. C. (2006). Understanding Information Technology Acceptance By Individual Perofessionals: Toward An Intergrative View. Information and Management, 43, 350-363. 